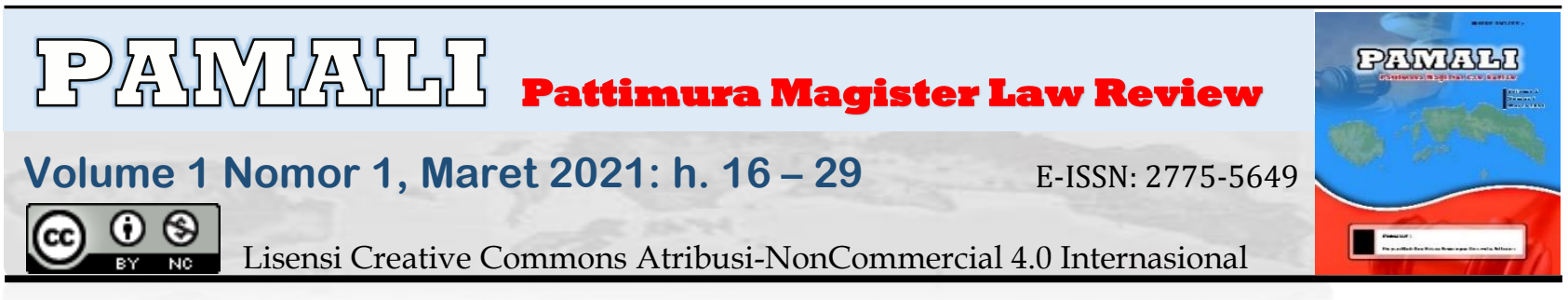

\title{
Konsinyasi/Penitipan Uang Sebagai Bentuk Ganti Rugi Atas Pengalihan Hak Tanah
}

\author{
Stevi Hendi Lawalata ${ }^{1}$, Jenny Kristiana Matuankotta ${ }^{2}$, Novyta Uktolseja ${ }^{3}$ \\ 1,2,3Fakultas Hukum Universitas Pattimura, Ambon, Indonesia. \\ @ : stevi.lawalata@gmail.com \\ doi : $x x x x x x x x x x x x x x x x$
}

Dikirim: 04/01/2021

\begin{tabular}{l}
\hline Info Artikel \\
\hline Keywords: \\
Consignment; Indemnity; \\
Transfer of Rights.
\end{tabular}

Kata Kunci:

Konsinyasi; Ganti Rugi; Pengalihan Hak.

\begin{abstract}
Direvisi: 20/02/2021 Dipublikasi: 24/02/2021
Abstract

Introduction: Securing land for the building of the Hunimua Ferry Crossing Port in Liang State, Central Maluku Regency, the deliberate mechanism that should be a means of compromise in the form of mutual compensation often does not reach a consensus, hence the way the dispute is resolved through the court's channel. On the other hand, in order for the completion of the assumed oil price to be paid by monetary or monetary services.

Purposes of the Research: The study will review payment procedures by conifers and other monetary services for the development of the Hunimua ferry crossing of maluku district as a transference of land rights.

Methods of the Research: The study is normatif yuridis, using analytic descriptive research types by using primary, secondary and tertiary source material. The approach used was a statute approach, a conceptual approach and a case approach. The technique for collecting legal materials used literature studies that were then analyzed qualitatively to address the issues discussed. Results of the Research: Payment procedures through consignment / deposit of money conducted by PT. ASDP Ferry (PERSERO) is in accordance with the provisions of the national land law in terms of the transfer of rights, which has been carried out according to land acquisition procedures through socialization and deliberation with land rights holders, but because the land is still in dispute, it is in accordance with the provisions of Law No. 2 of 2012, PT ASDP Fery Persero made a request for payment through consignment / deposit money. The consignment / deposit of money by PT ASDP Fery Persero for the construction of the Hunimua Ferry Crossing Port in Liang State, Central Maluku Regency has legal consequences for the transfer of land rights which are transferred from land rights holders to PT ASDP Fery Persero so that the construction activities of the Hunimua Ferry Port expansion can be carried out.
\end{abstract}


Negeri Liang Kabupaten Maluku Tengah sebagai satu peralihan hak atas tanah

Metode Penelitian: Penelitian ini adalah penelitian yuridis normatif, menggunakan tipe penelitian deskriptif analitis dengan menggunakan sumber bahan hukum primer, sekunder dan tersier. Pendekatan yang digunakan adalah pendekatan perundang-undangan (Statute Approach), pendekatan konseptual (conceptual approach) dan pendekatan kasus (Case Approach). Teknik pengumpulan bahan hukum menggunakan studi kepustakaan yang kemudian dianalisis secara kualitatif guna menjawab permasalahan yang dikaji.

Hasil Penelitian: Prosedur pembayaran melalui konsinyasi/penitipan uang yang dilakukan oleh PT. ASDP Ferry (PERSERO) telah sesuai dengan ketentuan hukum tanah nasional dalam hal proses pengalihan hak, yang mana telah dilakukan sesuai prosedur pengadaan tanah melalui sosialisasi dan musyawarah dengan pemegang hak atas tanah, namun karena tanah tersebut masih dalam sengketa, sehingga sesuai dengan ketentuan UU Nomor 2 Tahun 2012, PT ASDP Fery Persero melakukan permohonan penawaran pembayaran melalui konsinyasi/penitipan uang. Konsinyasi/penitipan uang oleh PT ASDP Fery Persero untuk pembangunan Pelabuhan Penyeberangan Ferry Hunimua di Negeri Liang Kabupaten Maluku Tengah berakibat hukum terhadap pengalihan hak atas tanah yang beralih dari pemegang hak atas tanah kepada PT ASDP Fery Persero sehingga kegiatan pembangunan perluasan Pelabuhan Penyeberangan Ferry Hunimua dapat dilaksanakan.

\section{Pendahuluan}

Pembangunan nasional yang dilaksanakan dalam rangka memenuhi amanat Pembukaan Undang-Undang Dasar Negara Republik Indonesia Tahun 1945 (selanjutnya disebut UUD NRI Tahun 1945) dari tahun ke tahun terus meningkat. Bersamaan dengan itu, jumlah penduduk terus bertambah dan sejalan dengan semakin meningkatnya pembangunan dan hasil-hasilnya, maka semakin meningkat dan beragam pula kebutuhan penduduk di Indonesia ${ }^{1}$.

Termasuk dalam kegiatan pembangunan nasional itu adalah pembangunan untuk kepentingan umum. Pembangunan untuk kepentingan umum ini harus terus diupayakan pelaksanaannya seiring dengan semakin bertambahnya jumlah penduduk yang disertai dengan semakin meningkatnya kemakmuranny ${ }^{2}$. Pengadaan tanah bagi pembangunan untuk kepentingan umum memberikan penghormatan terhadap pemegang hak atas tanah dengan memberikan perlindungan hukum dan dengan memberikan ganti kerugian yang adil dan layak kepada pihak yang berhak. ${ }^{3}$

Tanah adalah tempat bermukim manusia, sebagai sumber penghidupan juga menjadi tempat persemayaman terakhir manusia bahkan dalam filosofi budaya Jawa seperti yang dikutip Arie

1 Taufik Triwidyanto, "Proses Pengadaan Tanah Untuk Pembangunan Dan Kepentingan Umum Di Kota Surakarta” (Skripsi: Universitas Muhammadiyah Surakarta, 2009), h. 34. http:/ /eprints.ums.ac.id/4197/.

2 Eny Rochaida, “Dampak Pertumbuhan Penduduk Terhadap Pertumbuhan Ekonomi Dan Keluarga Sejahtera Di Provinsi Kalimantan Timur," Forum Ekonomi 18, no. 1 (2016): 14-24, h. 15. https://doi.org/10.29264/jfor.v18i1.42.

3 Fengky Kotalewala, Adonia Ivone Laturette, and Novyta Uktolseja, "Penyelesaian Sengketa Dalam Pengadaan Tanah Bagi Pembangunan Jalan Untuk Kepentingan Umum," SASI 26, no. 3 (2020): 415-433, https://doi.org/10.47268/sasi.v26i3.397, h. 415. 
Sukanthi Hutagalung dikenal istilah "sadumuk bathuk sanyari bumi, ditohi tumekaning patsi" 4 Berdasarkan kenyataan tersebut maka tanah bagi kehidupan manusia tidak saja mempunyai nilai ekonomis dan kesejahteraan semata, akan tetapi juga menyangkut masalah sosial, politik, budaya, psikologis bahkan juga mengandung aspek-aspek pertahanan dan keamanan nasional.

Menurut konsepsi hukum tanah nasional, seluruh bumi, air dan ruang angkasa termasuk kekayaan alam yang terkandung di dalamnya merupakan karunia Tuhan Yang Maha Esa dan merupakan kekayaan nasional, sehingga semua tanah yang ada di dalam wilayah negara kita adalah tanah bersama seluruh rakyat Indonesia, yang bersatu menjadi Bangsa Indonesia (Pasal 1 ayat (1)) Undang-Undang Nomor 5 Tahun 1960 Tentang Peraturan Dasar Pokok-Pokok Agraria (selanjutnya disebut UUPA).

Dalam rangka mewujudkan masyarakat yang adil, makmur, dan sejahtera berdasarkan Pancasila dan UUD NRI Tahun 1945, pemerintah perlu menyelenggarakan pembangunan. Salah satu upaya pembangunan dalam kerangka pembangunan nasional yang diselenggarakan pemerintah adalah pembangunan untuk kepentingan umum ${ }^{5}$.

Pembangunan untuk kepentingan umum tersebut memerlukan tanah yang pengadaannya dilaksanakan dengan mengedepankan prinsip yang terkandung di dalam UUD NRI Tahun 1945 dan hukum tanah nasional, antara lain prinsip kemanusiaan, keadilan, kemanfaatan, kepastian, keterbukaan, kesepakatan, keikutsertaan, kesejahteraan, keberlanjutan, dan keselarasan sesuai dengan nilai-nilai berbangsa dan bernegara ${ }^{6}$. Hukum tanah nasional mengakui dan menghormati hak masyarakat atas tanah dan benda yang berkaitan dengan tanah, serta memberikan wewenang yang bersifat publik ${ }^{7}$.

Provinsi Maluku merupakan salah satu provinsi yang dikenal dengan begitu banyak gugus pulau sehingga dijuluki Provinsi Seribu Pulau. Letak geografis yang dipisahkan oleh laut antara satu pulau dengan pulau yang lain membentuk karakter kehidupan masyarakat bergantung pada hasil laut. Kondisi ini juga mempengaruhi perkembangan transportasi di provinsi ini, dimana masyarakatnya dominan menggunakan transportasi laut sejak nenek moyang dengan menggunakan perahu layar dari satu pulau ke pulau yang lain bahkan menuju ke ibu kota provinsi yaitu Kota Ambon.

PT. ASDP Indonesia Ferry (Persero) (selanjutnya disebut PT. ASDP Ferry) adalah salah satu BUMN di Indonesia yang bergerak dalam jasa angkutan penyeberangan dan pengelola pelabuhan penyeberangan untuk penumpang, kendaraan dan barang. Fungsi utama perusahaan ini adalah menyediakan akses transportasi publik antar pulau yang bersebelahan serta menyatukan pulaupulau besar sekaligus menyediakan akses transportasi publik ke wilayah yang belum memiliki penyeberangan guna mempercepat pembangunan (penyeberangan perintis) ${ }^{8}$.

Sejalan dengan hal tersebut di atas, PT. ASDP INDONESIA FERRY (PERSERO) membutuhkan tanah seluas $+46.560 \mathrm{~m}^{2}$ di Hunimua, Negeri Liang, Kecamatan Salahutu, Kabupaten Maluku Tengah, untuk merenovasi dan memperbesar bangunan dermaga penyeberangan ferry yang telah

\footnotetext{
${ }^{4}$ Arie Sukanthi Hutagalung and Markus Gunawan, Kewenangan Pemerintah Di Bidang Pertanahan (Jakarta: Raja Grafindo Persada, 2008), h. vii.

5 Tim Penelitian Hukum, "Pelaksanaan Pengadaan Tanah Bagi Pembangunan Untuk Kepentingan Umum” (Jakarta, 2013), h. 1.

${ }^{6}$ Endang Purwaningsih and Derta Rahmanto, "Pengadaan Tanah Demi Kepentingan Umum Dalam Perjanjian Pengusahaan Jalan Tol (PPJT) Trans Sumatera," Lex Librum: Jurnal Ilmu Hukum 5, no. 2 (2019): 927-946, https://doi.org/10.46839/lljih.v5i2.140.

7 Abdul Latif, Hukum Administrasi Dalam Praktik Tindak Pidana Korupsi (Jakarta: Prenada Media Group, 2014).

8 Wikipedia, "ASDP Indonesia Ferry," wikipedia.org, 2020,

https://id.wikipedia.org/wiki/ASDP_Indonesia_Ferry.
} 
ada di bangun sebelumnya oleh Kementerian Perhubungan RI agar lebih baik dan representatif demi kenyamanan pengguna jasa penyeberangan. Terhadap kebutuhan tanah tersebut PT. ASDP INDONESIA FERRY (PERSERO) bermaksud untuk membayar ganti kerugian atas tanah seluas + $46.560 \mathrm{~m}^{2}$ kepada pemilik tanah.

Pada saat PT. ASDP INDONESIA FERRY (PERSERO) menerima tanah beserta bangunan dermaga penyeberangan ferry dari Kementerian Perhubungan RI sebagaimana tersebut di atas, tanah tersebut belum dilakukan pembayaran ganti kerugian kepada pemilik tanah, hal tersebut dikarenakan objek tanah tersebut sejak tahun 1981 sampai dengan tahun 2002 sedang menjadi objek perkara di Pengadilan antara ABDULLAH HAHUAN, THALIB LESSY maupun NADJAMUDIN LESSY dengan putusan tingkat akhir yaitu tidak ada menyebutkan pihak mana yang dinyatakan sebagai pihak yang berhak atas objek tanah sengketa tersebut (Putusan Peninjauan Kembali Mahkamah Agung Nomor: 179 PK/PDT/2002 Jo. Putusan Kasasi Mahkamah Agung Nomor: 4280 K/PDT/1989 Jo. Putusan Banding Pengadilan Tinggi Maluku Nomor: 79/Pdt/1982/PT.MAL Jo. Putusan Pengadilan Negeri Ambon Nomor: 377/1982/Pts.Perd.G/PN.AB dan Putusan Peninjauan Kembali Mahkamah Agung Nomor: 222 PK/Pdt/1992 Jo. Putusan Kasasi Mahkamah Agung Nomor: 125 K/Pdt/1990 Jo. Putusan Banding Pengadilan Tinggi Maluku Nomor: 58/Pdt/1985/PT.MAL Jo. Putusan Pengadilan Negeri Ambon Nomor: 9/1983/Perd.G/PN.AB). Selanjutnya pada tahun 2009 di atas tanah yang menjadi objek sengketa tersebut terbit Surat Sertifikat Hak Milik No: 1479 atas nama PAMA DJAMALI seluas $12.360 \mathrm{~m}^{2}$ dan Surat Sertifikat Hak Milik No: 1500 atas nama SALEH LESSY seluas $2.000 \mathrm{~m}^{2}$.

Berdasarkan fakta-fakta tersebut, PT. ASDP Indonesia Ferry (Persero) telah melakukan beberapa kali pertemuan dengan pihak / ahli waris baik dari ABDULLAH HAHUAN, THALIB LESSY, NADJAMUDIN LESSY maupun pemilik Surat Sertifikat Hak Milik No: 1479 seluas 12.360 $\mathrm{m}^{2}$ yaitu PAMA DJAMALI dan pemilik Surat Sertifikat Hak Milik No: 1500 seluas $2.000 \mathrm{~m}^{2}$ yaitu SALEH LESSY untuk bermusyawarah dan bernegosiasi serta melakukan koordinasi dengan pihakpihak lain yang dipandang dapat membantu guna penyelesaikan pembayaran ganti rugi tanah di pelabuhan penyeberangan Hunimua PT. ASDP Indonesia Ferry (PERSERO), namun para pihak / ahli waris tidak ada kesepakatan damai diantara mereka. Ketidaksepakatan ini bukan karena angka atau nilai rupiah yang akan dibayarkan tetapi dikarenakan masing-masing pihak / ahli waris merasa bahwa pihaknya yang paling berhak atas ganti rugi tanah tersebut (masih dipersengketakan kepemilikannya). Sehingga upaya pendekatan-pendekatan secara kekeluargaan, musyawarah dan negosiasi yang telah berjalan dari awal sampai dengan yang terakhir untuk pembayaran ganti rugi tersebut tidak menemukan kesepakatan dan dinyatakan gagal.

Dalam pengadaan tanah bagi pembangunan Pelabuhan penyeberangan Fery di Negeri Liang Maluku Tengah, mekanisme musyawarah yang seharusnya menjadi sarana untuk mencari jalan tengah terkait besaran ganti kerugian seringkali tidak mencapai kata sepakat, ada juga karena beberapa pihak yang bersengketa mengklaim sebagai pemilik lahan sehingga, berdasarkan hasil penilaian/appraisal harga tanah oleh Kantor Jasa Penilaian Publik (KJPP) dimana untuk menentukan besarnya nilai ganti rugi yang kemudian menitipkannya ke Pengadilan Negeri Ambon melalui prosedur konsinyasi dengan dikeluarkannya Penetapan Pengadilan Negeri Ambon Nomor 01Pdt.P-Konsinyasi/2017/PN Amb Tanggal 19 September 2017. Berdasarkan uraian di atas, maka dilakukan penelitian lebih mendalam dan kemudian mengkaji permasalahan tersebut.

\section{Metode Penelitian}

Jenis penelitian yang dipakai yaitu jenis penelitian yuridis normatif. Pada penelitian hukum nornatif yang sepenuhnya mempergunakan data sekunder, maka penyusunan kerangka teoritis yang bersifat tentatif dapat di tinggalkan, akan tetapi penyusunan kerangka konsepsionil mutlak di 
perlukan, maka di dalam menyusun kerangka konsepsionil di perlukan perumusan yang terdapat dalam peraturan perundang-undangan ${ }^{9}$

\section{Hasil dan Pembahasan}

\subsection{Prosedur Pembayaran Melalui Konsinyasi/Penitipan Uang Oleh PT. ASDP Ferry (PERSERO)}

\subsubsection{Pelaksanaan Pengadaan Tanah Dalam Pembangunan Pelabuhan Penyeberangan Ferry Hunimua di Negeri Liang Kabupaten Maluku Tengah}

Pengadaan tanah merupakan cara untuk memeroleh tanah untuk pembangunan bagi kepentingan umum. Pasal 18 Undang-Undang Pokok Agraria menyatakan bahwa: "untuk kepentingan umum, termasuk juga untuk kepentingan bangsa dan negara dan kepentingan bersama dari rakyat, hak atas tanah bisa dicabut, dengan cara memberi ganti kerugian yang layak dan sesuai dengan cara yang diatur dengan Undang-undang." Ketentuan tersebut menjadi dasar penjabaran pengaturan pengadaan tanah dalam Undang-Undang Nomor 2 Tahun 2012 tentang Pengadaan Tanah Bagi Pembangunan untuk Kepentingan Umum. Pasal 1 angka 2 undang-undang tersebut mengatur bahwa: "Pengadaan tanah adalah kegiatan menyediakan dengan cara memberi ganti kerugian yang layak dan adil kepada pihak yang berhak.

Dalam pelaksanaan penetapan lokasi tanah untuk perluasan dermaga penyeberangan fery di Hunimua Negeri Liang, Kecamatan Salahutu Kabupaten Maluku Tengah ini, lokasi tersebut adalah tanah milik beberapa orang warga masyarakat Negeri Liang yang ternyata masih dalam proses sengketa.

Sebagaimana telah disebutkan sebelumnya dalam bagian pendahuluan bahwa pada saat pada saat PT ASDP Ferry (Persero) menerima tanah beserta bangunan dermaga penyeberangan ferry dari Kementerian Perhubungan RI, tanah tersebut belum dilakukan pembayaran ganti kerugian kepada warga masyarakat yang mengklaim objek tanah tersebut adalah tanah miliknya dan sejak tahun 1981 sampai dengan tahun 2002 terjadilah saling gugat-menggugat antara mereka dengan putusan tingkat akhir yaitu tidak ada menyebutkan pihak mana yang dinyatakan sebagai pihak yang berhak atas objek tanah sengketa tersebut. Hal ini sesuai dengan Putusan Peninjauan Kembali Mahkamah Agung Nomor:179 PK/PDT/2002 Jo. Putusan Kasasi Mahkamah Agung Nomor: 4280 K/PDT/1989 Jo. Putusan Banding Pengadilan Tinggi Maluku Nomor: 79/Pdt/1982/PT.MAL Jo. Putusan Pengadilan Negeri Ambon Nomor: 377/1982/Pts.Perd.G/PN.AB dan Putusan Peninjauan Kembali Mahkamah Agung Nomor:222 PK/Pdt/1992 Jo. Putusan Kasasi Mahkamah Agung Nomor:125 K/Pdt/1990 Jo. Putusan Banding Pengadilan Tinggi Maluku Nomor: 58/Pdt/1985/PT.MAL Jo. Putusan Pengadilan Negeri Ambon Nomor:9/1983/Perd.G/PN.AB).

Dalam pelaksanaan pengadaan tanah untuk perluasan pelabuhan penyeberangan Ferry Hunimua di Negeri Liang Kecamatan Salahutu Kabupaten Maluku Tengah ini, dikarenakan objek objek tanah seluas $+46.560 \mathrm{~m}^{2}$ yang akan digantikan kerugiannya tersebut masih dipersengketakan kepemilikannya oleh para pihak yang masing-masing tetap mengklaim sebagai pemilik tanah tersebut., maka PT. ASDP Fery (Persero) sebagai Instansi yang memerlukan tanah berdasarkan Pasal 121 ayat (1) Peraturan Presiden RI Nomor 148 Tahun 2015 tentang Perubahan Keempat Atas Peraturan Presiden Nomor 71 Tahun 2012 tentang Penyelenggaraan Pengadaan Tanah Bagi Pembangunan Untuk Kepentingan Umum, melalui Jaksa Pengacara Negara pada Kejaksaan Negeri Maluku Tengah secara bersama-sama telah melakukan pertemuan-pertemuan dengan para pihak, baik secara kekeluargaan sebagai upaya musyawarah maupun negosiasi untuk menyelesaikan persengketaan kepemilikan tanah dimaksud secara damai.

9 Peter Mahmud Marzuki, Penelitian Hukum, (Jakarta: Kencana, 2007), h, 56. https://doi.org/340.072. 

berikut:

Pertemuan-pertemuan dengan para pihak dilaksanakan pada waktu dan tempat yaitu sebagai

1) Pertemuan I, diselenggarakan pada tanggal 1 Juni 2016 bertempat di Hotel Elizabeth Ambon;

2) Pertemuan II, diselenggarakan pada tanggal 4 Juni 2016 bertempat di Hotel Amaris Ambon;

3) Pertemuan III, diselenggarakan pada tanggal 22 Juni 2016 bertempat di The Natsepa Resort, Maluku Tengah, melibatkan Bupati Maluku Tengah, Sekda Maluku Tengah, Camat Salahutu, Raja Liang dan pihak TNI AURI Ambon;

4) Pertemuan IV, diselenggarakan pada tanggal 17 Agustus 2016 bertempat di Pendopo Kabupaten Maluku Tengah, Masohi, melibatkan Bupati Maluku Tengah dan Sekda Maluku Tengah.

Berdasarkan hasil pertemuan-pertemuan musyawarah maupun negosiasi yang telah dilakukan tersebut pada intinya semua para pihak tidak keberatan dan sepakat untuk menyerahkan tanah mereka kepada PT. ASDP Ferry (Persero) dengan ganti kerugian, namun para pihak tersebut tetap tidak ada kesepakatan damai, hal ini dikarenakan masing-masing pihak merasa pihaknya yang paling berhak atas pembayaran ganti kerugian tanah tersebut berdasarkan alas hak tanah ataupun putusan pengadilan yang telah berkekuatan hukum tetap (inkracht).

Untuk menindaklanjuti hasil pertemuan dengan para pihak di atas, pada tanggal 22 Februari 2017 bertempat di Hotel Amaris Ambon, PT. ASDP Ferry (Persero) juga telah mengundang para pihak dengan tujuan menyampaikan jumlah uang ganti kerugian yang nantinya akan di Konsinyasikan di Pengadilan Negeri Ambon. penyampaian jumlah uang Konsinyasi sebagaimana yang telah dijelaskan diatas, disampaikan oleh PT. ASDP Ferry (Persero) kepada para pihak berdasarkan hasil penilaian dari Kantor Jasa Penilai Publik MUHAMMAD ADLAN dan REKAN tertanggal 16 November 2016 dengan rincian sebagai berikut:

\begin{tabular}{|c|c|c|c|c|c|}
\hline No & Para Pihak & $\begin{array}{l}\text { Luas Tanah } \\
\quad(\mathbf{R p})\end{array}$ & Bangunan(Rp) & $\begin{array}{l}\text { Pepohonan } \\
\quad(\mathrm{Rp})\end{array}$ & $\begin{array}{l}\text { Jumlah Ganti } \\
\text { Kerugian } \\
(\mathbf{R p})\end{array}$ \\
\hline 1. & Pama Djamali. & $\begin{array}{l}12.360 \mathrm{~m}^{2}, \\
\text { Rp. } 1.705 .680 .000,-\end{array}$ & - & \multirow{5}{*}{$\begin{array}{l}137 \text { Batang, } \\
\text { Rp. } \\
\text { 102.750.000,- }\end{array}$} & \multirow{5}{*}{ Rp. 6.850.630.000,- } \\
\hline 2. & Saleh Lessy & $\begin{array}{l}2.000 \mathrm{~m}^{2}, \\
\text { Rp. } 276.000 .000,-\end{array}$ & $\begin{array}{l}\text { Penginapan } 186 \\
\mathrm{~m}^{2} \text { dan Rumah } \\
45 \mathrm{~m}^{2} \text { Rp. } \\
322.600 .000,-\end{array}$ & & \\
\hline 3 & Abdusamad & \multirow{3}{*}{$\begin{array}{l}32.200 \mathrm{~m}^{2} \\
\text { Rp. } 4.443 .600 .000,-\end{array}$} & \multirow{3}{*}{-} & & \\
\hline 4. & $\begin{array}{l}\text { Muhammad } \\
\text { Lessy }\end{array}$ & & & & \\
\hline 5. & Daud Hahuan & & & & \\
\hline
\end{tabular}

Menurut Pasal 10 huruf (d) dan Pasal 42 ayat (2) huruf (b) ke-2 Undang-Undang RI Nomor 2 Tahun 2012 tentang Pengadaan Tanah Bagi Pembangunan Untuk Kepentingan Umum, maka ganti kerugian atas tanah seluas $+46.560 \mathrm{~m}^{2}$ (termasuk pohon kelapa sebanyak 137 batang dan bangunan penginapan/rumah seluas $231 \mathrm{~m}^{2}$ yang berada diatas tanah tersebut) yang terletak di Hunimua, Negeri Liang, Kecamatan Salahutu, Kabupaten Maluku Tengah, dibayarkan dengan cara Konsinyasi (dititipkan) di Pengadilan Negeri setempat yaitu Pengadilan Negeri Ambon. Pada 
tanggal 19 September 2017 dikeluarkannya Penetapan Nomor: 01/Pdt. P. Konsinyasi/2017/PN Amb yang menyatakan bahwa konsinyasi yang diajukan oleh Pemohon telah sah untuk dilakukan. Penetapan itu berisikan sah dan berharga penawaran pembayaran dan penitipan sebagai konsinyasi dan menghukum Pemohon untuk membayar biaya perkara.

\subsubsection{Prosedur Pembayaran Melalui Konsinyasi/Penitipan Uang Oleh PT. ASDP Ferry (PERSERO)}

Hapusnya perikatan dengan cara konsinyasi diawali penawaran pembayaran. Penawaran pembayaran dilakukan oleh debitur atau dapat dilakukan juga oleh notaris atau juru sita disertai dua orang saksi kepada kreditur atau kuasanya pada waktu dan tempat yang telah disepakati saat akan berakhirnya perikatan dengan syarat utang telah terpenuhi semuanya. Penawaran pembayaran yang dilakukan oleh debitur ini mengalami penolakan dari kreditur, oleh karena itu berdasar Pasal 1406 KUH Perdata debitur dapat mengajukan penetapan penitipan di pengadilan setempat. Sebelum penitipan dilakukan, kreditur harus diberitahu mengenai tempat dan waktu dimana penawaran disimpan. Adanya penetapan konsinyasi dari pengadilan inilah yang mengakhiri segala perikatan yang terjadi antara kreditur dengan debitur.

Dasar hukum untuk melakukan konsinyasi salah satunya adalah Peraturan Kepala Badan Pertanahan Nasional Republik Indonesia Nomor 3 Tahun 2007 pada Pasal 34, apabila tanah telah diperoleh lebih dari 75\% (tujuh puluh lima persen) dari jumlah pemilik atau telah mencapai kesepakatan mengenai bentuk atau besarnya ganti kerugian, maka terhadap sisa tanah yang belum dibayarkan atau disetujui oleh sebagian kecil kurang dari 25\% (dua puluh lima persen) pemilik dapat dititipkan pada pengadilan negeri.

Undang-Undang Nomor 2 Tahun 2012 tentang Pengadaan Tanah Bagi Pembangunan Untuk Kepentingan Umum menyatakan, bahwa konsinyasi baru dapat dilakukan apabila masyarakat pemegang hak atas tanah menolak bentuk dan besarnya ganti kerugian berdasarkan hasil musyawarah. Konsinyasi atau penitipan uang diatur dalam Pasal 39 Undang-Undang Nomor 2 Tahun 2012, menyatakan bahwa selama 14 (empat belas) hari tidak ada pengajuan keberatan terhadap bentuk dan/atau besarnya ganti kerugian setelah dilakukan musyawarah sesuai ketentuan Pasal 38 ayat (1) Undang-Undang Nomor 2 Tahun 2012, maka secara hukum pihak yang berhak (dalam hal ini pemilik tanah) dianggap menerima bentuk dan besarnya ganti kerugian sesuai harga appraisal yang ditawarkan oleh Panitia Pengadaan Tanah. Pasal 42 ayat (1) UndangUndang Nomor 2 Tahun 2012 menyatakan bahwa ganti kerugian dapat dititipkan di pengadilan negeri setempat terhadap pihak yang menolak bentuk dan/atau besarnya ganti kerugian berdasarkan hasil musyawarah.

Konsinyasi atau penitipan uang ini berguna dalam mempercepat proses pengadaan tanah yang dilakukan oleh pemerintah dalam keadaan yang memaksa. Masalah ganti rugi merupakan isu sentral yang paling rumit penanganannya dalam upaya pengadaan tanah oleh pemerintah dengan memanfaatkan tanah-tanah hak, karena pada hakikatnya ganti rugi merupakan konsenkuensi yang melekat pada proses pengadaan tanah.

Ganti kerugian yang dimaksud adalah penggantian yang layak dan adil kepada pihak yang berhak terhadap proses pengadaan tanah. Hal ini sejalan dengan teori keadilan sebagaimana yang dikemukakan oleh Jhon Rawls yang berpandangan bahwa keadilan adalah prinsip-prinsip yang akan dipilih secara rasional oleh orang sebelum ia tahu kedudukannya dalam masyarakat (original position). Menurut Rawls cara yang adil untuk menyatukan berbagai kepentingan yang berbeda adalah melalui keseimbangan kepentingan tersebut. Masyarakat sebagai pemilik hak atas tanah tentunya membutuhkan adanya ganti kerugian yang adil menurut masyarakat. Oleh karena itulah ganti kerugian yang dilakukan oleh pemerintah misalnya dalam bentuk uang, maka harus sesuai 
perhitungan yang wajar. Ganti kerugian dihitung berdasarkan nilai pada saat pengumuman penetapan lokasi pembangunan untuk kepentingan umum yang dilakukan oleh Lembaga Pertanahan.

Pembayaran ganti kerugian tersebut harus kepada pemilik tanah yang berhak tidak diperkenankan dilakukan melalui perantara atau kuasanya. Pembayaran ganti rugi harus dilakukan secara tunai dan dibayarkan langsung kepada yang berhak sesuai dengan kesepakatan mengenai besarnya nilai dan bentuk ganti kerugian yang telah disepakati.

Adanya konsinyasi ini berakibat hubungan hukum antara pemilik tanah dengan tanahnya dapat diputus dan proses pembangunan bagi kepentingan umum dapat terlaksana secara tepat waktu. Dari apa yang dipaparkan di atas, maka dalam pengadaan tanah untuk pembangunan perluasan Pelabuhan Penyeberangan Ferry Hunimua di Negeri Liang, Kecamatan Salahutu Kabupaten Maluku Tengah dilaksanakan sebagaimana ditentukan dalam Pasal 42 Undang-Undang Nomor 2 Tahun 2012 tersebut. Artinya bahwa pada saat PT ASDP Fery Persero melakukan beberapa kali musyawarah dengan pihak-pihak yang mengaku sebagai pemegang hak atas tanah tersebut, tetapi tidak ditemukan satu kesepakatan siapa yang berhak sebagai pemegang hak atas tanah. Sehingga, PT ASDP Fery Persero mengajukan permohonan konsinyasi/penitipan uang ke pengadilan Negeri Ambon. Pada tanggal 19 September 2017 Pengadilan Negeri Ambon mengabulkan permohonan tersebut melalui Penetapan Pengadilan Negeri Ambon Nomor 01/Pdt.P-Konsinyasi/2017/PN. Amb.

\subsubsection{Kesesuaian Pembayaran Melalui Konsinyasi/Penitipan Uang Oleh PT. ASDP Ferry (PERSERO) dengan ketentuan hukum sebagai proses pengalihan hak}

Kegiatan menyediakan tanah yang dilakukan oleh pemerintah harus didasari ketentuan Pasal 6 Undang- Undang Nomor 5 Tahun 1960 tentang Peraturan Dasar Pokok-Pokok Agraria mengenai fungsi sosial tanah, artinya bahwa tanah tidak hanya berfungsi bagi pemegang hak atas tanahnya saja tetapi juga bagi bangsa Indonesia seluruhnya. Berarti bahwa harus ada keseimbangan antara kepentingan individu (pemilik, penguasa, penyewa) dengan kepentingan masyarakat dan negara, dalam pendayagunaan tanah tersebut.

Boedi Harsono menyebutkan bahwa asas-asas yang berlaku mengenai penguasaan tanah dan perlindungan hukum yang diberikan oleh Hukum Tanah Nasional terhadap pemengang hak atas tanah adalah ${ }^{10}$ :

1) Bahwa penguasaan dan penggunaan tanah oleh siapapun dan untuk keperluan apapun, harus dilandasi hak atas tanah.

2) Bahwa penguasaan dan penggunaan tanah tanpa adanya landasan haknya tidak dibenarkan, bahkan diancam dengan sanksi pidana.

3) Bahwa penguasaan dan penggunaan tanah yang telah dilandasi hak atas tanah yang disediakan oleh Hukum Tanah Nasional, dilindungi oleh hukum terhadap gangguan pihak manapun.

4) Bahwa oleh hukum di sediakan berbagai sarana hukum untuk menanggulangi gangguan yang ada.

5) Bahwa dalam keadaan biasa bila diperlukan oleh siapapun dan untuk keperluan apapun perolehan tanah yang dihaki seseorang, harus melalui musyawarah agar tercapai kesepakatan.

10 Boedi Harsono, Hukum Agraria Indonesia, Sejarah Pembentukan Undang-Undang Pokok Agraria, Isi Dan Pelaksanaannya (Jakarta: Djambatan, 2007), h. 342. 
6) Dalam keadaan biasa, tidak dibenarkan adanya paksaan dalam bentuk apapun dan oleh siapapun terhadap pemegang hak atas tanahnya.

7) Dapat dilakukan pencabutan hak sesuai aturan dalam Undang- Undang Nomor 20 Tahun 1960 dalam keadaan yang memaksa, karena tanah yang bersangkutan untuk kepentingan umum yang tidak memungkinkan untuk diganti tempat lain dan tidak berhasil memperoleh kesepakatan.

8) Bahwa dalam perolehan atau pengambilan tanah baik atas dasar kesepakatan atau pencabutan hak, pemengang hak berhak memperoleh imbalan atau ganti kerugian yang bukan hanya meliputi tanahnya, bangunan, dan tanaman miliknya, melainkan kerugiankerugian lain yang dideritanya akibat penyerahan tanah yang bersangkutan.

9) Bahwa bentuk dan jumlah imbalan yang diberikan tidak boleh menyebabkan pemegangnya mengalami kemunduran dibidang sosial dan ekonominya.

Terkait dengan Teori kepastian hukum, menurut Gustav Radbruch yang dikutip oleh Theo Huijbers mengatakan bahwa kepastian hukum merupakan salah satu diantara tiga aspek yang diperlukan di samping keadilan dalam arti sempit dan tujuan keadilan atau finalitas untuk sampai pada pengertian hukum yang memadai. Aspek kepastian hukum atau legalitas menjamin bahwa hukum dapat berfungsi sebagai peraturan yang harus ditaati. Oleh karena itu, prosedur pembayaran melalui konsinyasi/penitipan uang oleh PT ASDP Fery Persero juga harus sesuai dengan hukum positif. Artinya bahwa apa yang diatur di dalam ketentuan peraturan perundang-undangan mengenai konsinyasi/penitipan uang itu, wajib untuk dilaksanakan oleh PT. ASDP Fery Persero. Dalam pelaksanaannya, prosedur konsinyasi atau penitipan uang di pengadilan oleh PT. ASDP Fery Persero sudah melalui prosedur dalam ketentuan perundangundangan yang berlaku. Sehingga pada akhirnya pelaksanaan konsinyasi ini, diharapkan dapat menimbulkan sebuah kepastian hukum baik bagi pemilik tanah yang bersengketa maupun bagi PT ASDP Fery Persero.

Sesuai dengan penjelasan di atas, maka dalam perbuatan konsinyasi/penitipan uang sebagai bentuk pengalihan hak untuk pembangunan pelabuhan penyeberangan ferry Hunimua di Negeri Liang Kabupaten Maluku Tengah telah sesuai dengan ketentuan dan prosedur sebagaimana ditetapkan dalam ketentuan hukum tanah nasional yang diawali dengan musyawarah dengan para pemilik tanah yang masih bersengketa soal kepemilikan tanah. Karena musyawarah tidak menemukan solusi akibat dari adanya klaim kepemilikan tanah tersebut oleh beberapa pihak yang mengaku sebagai pemilik tanah yang sah. Oleh karena itulah, PT ASDP Ferry Persero melakukan proses konsinyai ke Pengadilan Negeri Ambon dengan perhitungan ganti rugi yang wajar sesuai dengan NJOP tanah tersebut yang dilakukan oleh apraisal.

\subsection{Akibat Konsinyasi/Penitipan Uang Pada Pembangunan Pelabuhan Penyeberangan Ferry Hunimua di Negeri Liang Kabupaten Maluku Tengah Sebagai Peralihan Hak Atas Tanah}

\subsubsection{Pengaruh Konsinyasi/Penitipan Uang Pada Pembangunan Pelabuhan Penyeberangan Ferry Hunimua di Negeri Liang}

Permasalahan pembangunan di Indonesia dibagi menjadi dua bagian besar yaitu masalah obyek Masalah pembebasan tanah sangat rawan dalam penanganannya, karena di dalamnya menyangkut hajat hidup orang banyak, apabila dilihat dari kebutuhan pemerintah akan tanah untuk keperluan pembangunan, dapatlah dimengerti bahwa tanah negara yang tersedia sangatlah terbatas, oleh karena itu satu-satunya cara yang dapat ditempuh adalah dengan membebaskan 
tanah milik masyarakat, baik yang telah di kuasai dengan hak berdasarkan Hukum Adat maupun hak-hak lainnya menurut UUPA ${ }^{11}$.

Kegiatan pengadaan tanah untuk kepentingan umum dalam rangka pembangunan jalan tol tersebut terdapat kendala yang dihadapi oleh Panitia Pelaksana Pengadaan Tanah (PPT) dan dibantu oleh pegawai kantor Pejabat Pembuat Komitmen (PPK). Salah satu diantaranya yaitu terdapat beberapa pihak yang tanahnya tidak mau dilakukan pencabutan hak dengan alasan tanah tersebut adalah hak milik mereka, padahal dalam Pasal 6 Undang- Undang Nomor 5 Tahun 1960 tentang Peraturan Dasar Pokok-Pokok Agraria menyebutkan bahwa "Semua hak atas tanah mempunyai fungsi sosial". Maksud dari fungsi sosial disini adalah bahwa segala hak atas tanah digunakan sebesar-besarnya untuk kesejahteraan warga Negara Indonesia sehingga tanah milik masyarakat khususnya warga negara Indonesia dapat diambil alih hak kepemilikannya oleh negara.

Berdasarkan hal tersebut tim PPT dengan para pihak terkait yang telah melakukan musyawarah kepada para warga berdasarkan ketentuan Pasal 42 Undang-Undang Nomor 2 Tahun 2012 tentang Pengadaan Tanah Bagi Pembangunan Untuk Kepentingan Umum melakukan kegiatan penitipan uang ganti rugi (konsinyasi) yang dititipkan di Pengadilan Negeri setempat.

Sehingga konsekuensi yang diterima oleh para pemegang hak atas tanah yaitu tanah mereka menjadi milik negara, namun para pemegang hak atas tanah juga dapat mengajukan gugatan keberatan ke pengadilan negeri terkait dengan penetapan nilai ganti rugi yang menurut rumusan Pasal 1 angka (10) Undang-Undang Nomor 2 Tahun 2012 adalah penggantian yang layak dan adil kepada pihak yang berhak dalam proses pengadaan tanah.

Penetapan besarnya nilai ganti rugi dalam pengadaan tanah bagi pembangunan untuk kepentingan umum dilakukan oleh Ketua Pelaksana Pengadaan Tanah berdasarkan hasil penilaian jasa penilai/penilai publik (Pasal 63 ayat (1) Peraturan Presiden Nomor 99 Tahun 2014 tentang Perubahan Kedua Atas Peraturan Presiden Nomor 71 Tahun 2012 tentang Penyelenggaraan Pengadaan Tanah Bagi Pembangunan Untuk Kepentingan Umum).

Sebelum para pihak pemegang hak atas tanah melakukan gugatan ke pengadilan negeri, Panitia Pelaksana Pengadaan Tanah melaksanakan musyawarah dengan pihak yang berhak dalam waktu 30 (tiga puluh) hari sejak diterimanya hasil penilaian dari penilai, selanjutnya hasil kesepakatan dari musyawarah tersebut menjadi dasar pemberian ganti rugi kepada pihak yang berhak yang dimuat dalam berita acara kesepakatan (Pasal 37 Undang-Undang No 2 Tahun 2012).

Apabila dalam hal tidak tercapai kesepakatan mengenai bentuk dan besarnya ganti rugi, pihak yang berhak dapat mengajukan keberatan kepada Pengadilan Negeri setempat dalam jangka waktu 14 (empat belas) hari setelah musyawarah penetapan ganti rugi, selanjutnya Pengadilan Negeri akan memutus dalam waktu paling lama 30 (tiga puluh) hari sejak diterimanya pengajuan keberatan. Apabila pihak yang berhak menolak terhadap putusan Pengadilan Negeri tersebut, maka dalam jangka waktu 14 (empat belas) hari pihak yang berhak dapat mengajukan kasasi ke Mahkamah Agung, selanjutnya Mahkamah Agung wajib memberikan Putusan dalam waktu paling lama 30 (tiga puluh) hari sejak permohonan kasasi diterima. Putusan kasasi yang telah berkekuatan hukum tetap tersebut menjadi dasar pemberian ganti rugi kepada pihak yang berhak (Pasal 38 Undang-Undang Nomor 2 Tahun 2012).

11 S. D Marlijanto, “Konsinyasi Ganti Rugi Dalam Pengadaan Tanah Untuk Kepentingan Umum (Studi Pengadaan Tanah Untuk Pembangunan Proyek Jalan Tol Semarang-Solo Di Kabupaten Semarang)" (Tesis: Universitas Diponegoro, 2010), h. 86. 
Penitipan ganti rugi melalui pengadilan bersumber pada ketentuan Undang-Undang Nomor 2 Tahun 2012 berikut peraturan pelaksanaannya. Berdasarkan Pasal 42 dan Pasal 43 UndangUndang Nomor 2 Tahun 2012 tentang Pengadaan Tanah Bagi Pembangunan Untuk Kepentingan Umum dalam hal pihak yang berhak menolak bentuk dan/atau besarnya ganti rugi berdasarkan hasil musyawarah sebagaimana diatur dalam Pasal 37, atau Putusan Pengadilan Negeri/Mahkamah Agung sebagaimana dimaksud Pasal 38, ganti rugi dititipkan di Pengadilan Negeri setempat.

Penitipan ganti rugi juga dapat dilakukan terhadap:

1) Pihak yang berhak menerima ganti rugi tidak diketahui keberadaannya.

2) Objek pengadaan tanah yang akan diberikan ganti rugi sedang menjadi objek perkara di Pengadilan, masih dipersengketakan kepemilikkannya, diletakkan sita oleh pejabat yang berwenang atau menjadi jaminan di bank.

Sebagaimana telah disebutkan sebelumnya bahwa pelaksanaan pengadaan tanah bagi pembangunan untuk kepentingan umum terkait dengan proyek pembangunan pelabuhan penyeberangan Fery Hunimua sudah dilaksanakan dan disesuaikan berdasarkan Undang-Undang Nomor 2 Tahun 2012 tentang Pengadaan Tanah Bagi Pembangunan Untuk Kepentingan Umum sebagai dasar peraturan pokoknya dan Peraturan Presiden Republik Indonesia Nomor 71 Tahun 2012 tentang Penyelenggaraan Pengadaan Tanah Bagi Pembangunan Untuk Kepentingan Umum jo Peraturan Presiden Nomor 40 Tahun 2014 tentang Perubahan Atas Peraturan Presiden Nomor 71 Tahun 2012 tentang Penyelenggaraan Pengadaan Tanah Bagi Pembangunan Untuk Kepentingan umum jo Peraturan Presiden Nomor 99 Tahun 2014 tentang Perubahan Kedua Atas Peraturan Presiden Nomor 71 Tahun 2012 tentang Penyelenggaraan Pengadaan Tanah Bagi Pembangunan Untuk Kepentingan umum jo Peraturan Presiden Nomor 30 Tahun 2015 tentang Perubahan Ketiga Atas Peraturan Presiden Nomor 71 Tahun 2012 tentang Penyelenggaraan Pengadaan Tanah Bagi Pembangunan Untuk Kepentingan umum jo Peraturan Presiden Nomor 148 Tahun 2015 Tentang Perubahan Keempat Atas Peraturan Presiden Nomor 71 Tahun 2012 tentang Penyelenggaraan Pengadaan Tanah Bagi Pembangunan Untuk Kepentingan umum sebagai peraturan teknis pelaksanaannya.

Dengan demikian, ketentuan peraturan perundang-undangan di atas, sejalan dengan teori penyelenggaraan kepentingan umum yaitu bahwa tujuan/tugas pemerintah meliputi keseluruhan tindakan, perbuatan dan keputusan dari alat-alat pemerintahan untuk mencapai tujuan pemerintahan yaitu bukan saja tercapainya suatu ketertiban di dalam masyarakat akan tetapi juga tercapainya tujuan nasional atau kepentingan bersama/ umum. Melalui hukum positif yang berlaku mengenai hukum tanah nasional maka penyelenggaraan pengadaan tanah bagi pembangunan untuk kepentingan umum dapat terlaksana mesikpun memang dalam pelaksanaan seringkali terjadi pertentangan hak dan kewajiban dari para pihak.

Oleh Karena itulah, dengan telah sesuainya pelaksanaan pengadaan tanah bagi pembangunan pelabuhan penyeberangan Fery Hunimua di Negeri Liang maka konsinyasi/penitipan uang memberikan pengaruh dan solusi bagi pengadaan tanah bagi pembangunan pelabuhan penyeberangan Fery Hunimua. Konsinyasi menjadi salah satu cara bagi PT. ASDP Fery Persero untuk dapat melakukan kegiatan pembangunan pelabuhan penyeberangan Fery Hunimua di atas tanah milik para pihak yang mengklaim dan masih bersengketa terkait kepemilikan tanah tersebut tentunya dengan adanya perhitungan ganti kerugian yang wajar. 


\subsubsection{Konsinyasi/Penitipan Uang Sebagai Bentuk Peralihan Hak Atas Tanah Pada Pembangunan Pelabuhan Penyeberangan Ferry Hunimua di Negeri Liang Kabupaten Maluku Tengah}

Pelepasan hak atas tanah dapat diserahkan secara sukarela atau ada ganti rugi kepada pemilik tanah. Penyerahan secara sukarela atau dengan ganti rugi inilah yang disebut melepaskan hak, dalam prakteknya istilah sukarela itu tidak murni lagi, sebab ada unsur ganti rugi, dalam bahasa sehari-hari penyerahan sukarela seperti itu adalah akibat tindakan penggusuran oleh suatu pihak yang menang dalam sengketa tanah di pengadilan ${ }^{12}$. Peralihan hak atas tanah adalah berpindahnya hak atas tanah dari pemegang hak yang lama kepada pemegang hak yang baru menurut ketentuan peraturan perundang-undangan yang berlaku. Peralihan hak atas tanah akibat adanya konsinyasi/penitipan uang ganti kerugian didasarkan pada Undang-Undang Nomor 2 tahun 2012. Pasal 41 ayat (1) Undang-Undang Nomor 2 tahun 2012 menyebutkan Ganti Kerugian diberikan kepada Pihak yang Berhak berdasarkan hasil penilaian yang ditetapkan dalam musyawarah sebagaimana dimaksud dalam Pasal 37 ayat (2) dan/atau putusan pengadilan negeri/Mahkamah Agung sebagaimana dimaksud dalam Pasal 38 ayat (5). Pada saat pemberian Ganti Kerugian pihak yang berhak menerima ganti kerugian wajib, melakukan pelepasan hak dan menyerahkan bukti penguasaan atau kepemilikan Objek Pengadaan Tanah kepada instansi yang memerlukan tanah melalui Lembaga Pertanahan.

Pihak yang Berhak menerima Ganti Kerugian bertanggung jawab atas kebenaran dan keabsahan bukti penguasaan atau kepemilikan yang diserahkan. Tuntutan pihak lain atas Objek Pengadaan Tanah yang telah diserahkan kepada instansi yang memerlukan tanah menjadi tanggung jawab Pihak yang berhak menerima Ganti Kerugian. setiap orang yang melanggar ketentuan dikenai sanksi pidana sesuai dengan ketentuan peraturan perundang-undangan.

Pada saat pelaksanaan pemberian Ganti kerugian dan Pelepasan Hak sebagaimana dimaksud dalam Pasal 41 ayat 2 huruf a UU Nomor 2 tahun 2012 telah dilaksanakan atau pemberian pemberian Ganti Kerugian sudah dititipkan di pengadilan negeri sebagaimana dimaksud dalam Pasal 42 ayat 1 UU Nomor 2 tahun 2012, kepemilikan atau Hak Atas Tanah dari Pihak yang Berhak menjadi hapus dan alat bukti haknya dinyatakan tidak berlaku dan tanahnya menjadi tanah yang di kuasai langsung oleh negara.

Jika dikaji dengan Teori Kepastian Hukum melalui pandangan Theo Huijbers yang mengatakan bahwa kepastian hukum merupakan salah satu diantara tiga aspek yang diperlukan di samping keadilan dalam arti sempit dan tujuan keadilan atau finalitas untuk sampai pada pengertian hukum yang memadai. Ketentuan hukum tanah nasional mengenai ganti kerugian melalui kosinyasi/penitipan uang sudah jelas diatur dalam UU Nomor 2 Tahun 2012. Sehingga ketentuan ini harus diimplementasikan dalam proses pengadaan tanah bagi pembangunan untuk kepentingan, sehingga tujuan kepastian hukum itu dapat terwujud.

Dalam UU Nomor 2 Tahun 2012 Pasal 44 ayat 1 Pihak yang berhak menerima Ganti Kerugian atau instansi yang memperoleh tanah dalam Pengadaan Tanah untu Kepentingan Umum dapat diberikan insentif perpajakan. Selanjutnya pada ayat (2) Ketentuan lebih lanjut mengenai insentif perpajakan diatur oleh Pemerintah atau Pemerintah Daerah sesuai dengan kewenangannya.

12 Desy Kosita Hallauw, Jenny Kristiana Matuankotta, and Novyta Uktolseja, “Analisis Hukum Surat Pelepasan Hak Atas Tanah Adat (Dati) Di Kota Ambon," SASI 26, no. 1 (2020): 111-118, https://doi.org/10.47268/sasi.v26i1.256, h. 114. 
Secara teknis bila terjadi penolakan atas bentuk dan besaran ganti rugi maka pihak yang berhak dapat mengajukan keberatan kepada pengadilan negeri setempat dalam waktu paling lama 14 hari kerja setelah ditandatangani berita acara hasil musyawarah. Hal ini dijelaskan dalam Pasal 73 ayat 1 Perpres No. 71 Tahun 2012 Tentang Penyelenggaraan Pengadaan Tanah Bagi Pembangunan Untuk Kepentingan Umum. Dalam ayat 2 pasal tersebut diterangkan selanjutnya bahwa Pengadilan Negeri berhak memutus bentuk dan/atau besarnya ganti kerugian dalam waktu paling lama 30 hari kerja sejak diterimanya pengajuan keberatan. Sementara ayat 3 menjelaskan bahwa pihak yang keberatan terhadap putusan Pengadilan Negeri sebagaimana dimaksud pada ayat 2 dalam waktu paling lama 14 hari kerja dapat mengajukan kasasi kepada Mahkamah Agung. Ayat 4 menjelaskan bahwa Mahkamah Agung wajib memberikan putusan dalam waktu paling lama 30 hari kerja sejak permohonan kasasi diterima.

Maria SW Sumardjono menilai bahwa waktu 14 hari adalah waktu yang sangat singkat bagi pihak yang berhak untuk mengajukan keberatan. Sehingga apabila ketentuan tersebut tidak mendapat sosialisasi dimasyarakat, akan terjadi keributan dimasyarakat karena apabila telah lewat dari 14 hari dianggap menerima putusan pengadilan negeri ${ }^{13}$.

Selanjutnya pada tahap kasasi, ketika keputusan mahkamah agung sudah dikeluarkan, maka pada hakikatnya saat itulah pihak yang berhak sudah tidak lagi memiliki hubungan hukum dengan tanahnya karena telah hapus.

Berdasarkan uraian di atas, maka jelaslah bahwa pada saat dikabulkannya permohonan penawaran ganti kerugian melalui konsinyasi/penitipan uang melalui Penetapan Konsinyasi Pengadilan negeri Ambon Nomor 01/Pdt.P-Konsinyasi/2017/PN Ambon yang kemudian tidak di ajukan keberatan oleh para pihak yang mengklaim sebagai pemegang hak atas tanah tersebut dalam jangka waktu 14 hari, maka secara hukum menurut UU Nomor 2 Tahun 2012 hak atas tanah dari pihak-pihak yang mengklaim kepemilikan tanah tersebut menjadi hapus. Artinya bahwa hak atas tanah tersebut menjadi beralih dari pihak-pihak tersebut kepada pemerintah, dalam hal ini PT ASDP Fery Indonesia.

Dengan beralihnya hak atas tanah dari para pihak yang mengklaim kepemilikan tanah tersebut kepada PT ASDP Fery Persero, maka secara hukum, PT ASDP Fery dapat melakukan kegiatan perluasan pembangunan pelabuhan penyeberangan fery Hunimua di atas tanah tersebut.

\section{Kesimpulan}

Prosedur pembayaran melalui konsinyasi/penitipan uang yang dilakukan oleh PT. ASDP Ferry (PERSERO) telah sesuai dengan ketentuan hukum tanah nasional dalam hal proses pengalihan hak, yang mana telah dilakukan sesuai prosedur pengadaan tanah melalui sosialisasi dan musyawarah dengan pemegang hak atas tanah, namun karena tanah tersebut masih dalam sengketa, sehingga sesuai dengan ketentuan Undang-Undang Nomor 2 Tahun 2012 Tentang Pengadaan Tanah Bagi Pembangunan Untuk Kepentingan Umum, PT ASDP Fery Persero melakukan permohonan penawaran pembayaran melalui konsinyasi/penitipan uang.

Konsinyasi/penitipan uang oleh PT ASDP Fery Persero untuk pembangunan Pelabuhan Penyeberangan Ferry Hunimua di Negeri Liang Kabupaten Maluku Tengah berakibat hukum terhadap pengalihan hak atas tanah yang beralih dari pemegang hak atas tanah kepada PT ASDP Fery Persero sehingga kegiatan pembangunan perluasan Pelabuhan Penyeberangan Ferry Hunimua

${ }^{13}$ DPR RI, “Rapat Dengar Pendapat Umum: Mendengarkan Pendapat Pakar” (Jakarta, 2011), h. 227. 
dapat dilaksanakan. Walaupun demikian, konsinyasi/penitipan uang tidak secara serta merta menyebabkan PT. ASDP Ferry Persero dapat melakukan pembangunan Pelabuhan Penyeberangan Ferry Hunimua karena harus memenuhi semua persyaratan guna pelaksanaan pembangunan.

\section{Ucapan Terima Kasih (Acknowledgments)}

Penulis mengucapkan terima kasih kepada pihak-pihak yang telah berkontribusi dalam penelitian, khususnya kepada Direktur SDM dan Layanan Korporasi, Vice President Pengelolaan SDM PT. ASDP Indonesia Ferry (Persero) dan General Manager Cabang Ambon PT. ASDP Indonesia Ferry (Persero) yang selalu memberikan dukungan dan motivasi bagi penulis sehingga penelitian ini dapat terlaksana dengan baik.

\section{Referensi}

DPR RI. “Rapat Dengar Pendapat Umum: Mendengarkan Pendapat Pakar.” Jakarta, 2011.

Hallauw, Desy Kosita, Jenny Kristiana Matuankotta, and Novyta Uktolseja. "Analisis Hukum Surat Pelepasan Hak Atas Tanah Adat (Dati) Di Kota Ambon." SASI 26, no. 1 (2020): 111-118. https://doi.org/10.47268/sasi.v26i1.256.

Harsono, Boedi. Hukum Agraria Indonesia, Sejarah Pembentukan Undang-Undang Pokok Agraria, Isi Dan Pelaksanaannya. Jakarta: Djambatan, 2007.

Hutagalung, Arie Sukanthi, and Markus Gunawan. Kewenangan Pemerintah Di Bidang Pertanahan. Jakarta: Raja Grafindo Persada, 2008.

Kotalewala, Fengky, Adonia Ivone Laturette, and Novyta Uktolseja. "Penyelesaian Sengketa Dalam Pengadaan Tanah Bagi Pembangunan Jalan Untuk Kepentingan Umum." SASI 26, no. 3 (2020): 415-433. https:/ / doi.org/10.47268/sasi.v26i3.397.

Latif, Abdul. Hukum Administrasi Dalam Praktik Tindak Pidana Korupsi. Jakarta: Prenada Media Group, 2014.

Marlijanto, S. D. "Konsinyasi Ganti Rugi Dalam Pengadaan Tanah Untuk Kepentingan Umum (Studi Pengadaan Tanah Untuk Pembangunan Proyek Jalan Tol Semarang-Solo Di Kabupaten Semarang)." Tesis: Universitas Diponegoro, 2010.

Marzuki, Peter Mahmud. Penelitian Hukum, Jakarta: Kencana, 2007. https:// doi.org/340.072.

Purwaningsih, Endang, and Derta Rahmanto. "Pengadaan Tanah Demi Kepentingan Umum Dalam Perjanjian Pengusahaan Jalan Tol (PPJT) Trans Sumatera." Lex Librum: Jurnal Ilmu Hukum 5, no. 2 (2019): 927-946. https:/ / doi.org/10.46839/lljih.v5i2.140.

Rochaida, Eny. "Dampak Pertumbuhan Penduduk Terhadap Pertumbuhan Ekonomi Dan Keluarga Sejahtera Di Provinsi Kalimantan Timur." Forum Ekonomi 18, no. 1 (2016): 14-24. https://doi.org/10.29264/jfor.v18i1.42.

Tim Penelitian Hukum. "Pelaksanaan Pengadaan Tanah Bagi Pembangunan Untuk Kepentingan Umum." Jakarta, 2013.

Triwidyanto, Taufik. "Proses Pengadaan Tanah Untuk Pembangunan Dan Kepentingan Umum Di Kota Surakarta." Universitas Muhammadiyah Surakarta, 2009. http:// eprints.ums.ac.id/4197/.

Wikipedia. "ASDP Indonesia Ferry." 2020. https://id.wikipedia.org/wiki/ASDP_Indonesia_Ferry. 